\title{
ANALISIS KANDUNGAN BORAKS PADA KERUPUK NASI YANG DIJUAL DI PASAR TRADISIONAL KABUPATEN TANGGAMUS SECARA SPEKTROFOTOMETRI UV-Vis
}

\author{
An Analysis On Borax Content In Rice Crackers Sold In Traditional Markets Tanggamus \\ District With Spectrophotometry UV-Vis
}

\author{
Samsuar', Akhmad Rokiban' ${ }^{1}$, Suparsi ${ }^{2}$ \\ Farmasi-FMIPA Universitas Tulang Bawang, ${ }^{2}$ RS Panti Secanti Lampung \\ Email : mrsam_utb@yahoo.co.id \\ 082379693276
}

\begin{abstract}
The use of additional subtance for food is to increase or to maintain nutritional value and quality of storability. Our govermment prohibits the use of borax as an additives subtance for food as appointed in Permenkes No.033, 2012. Borax is a chemical compound in white colorless crystalline with a chemical formula $\mathrm{Na}_{2} \mathrm{~B}_{4} \mathrm{O}_{7} 10 \mathrm{H}_{2} \mathrm{O}$. Rice crackers are crackers made from rice with spices and flavor enhancer. In manufacturing crackers Borax is sometimes added to get savory crackers and to make them swelling. The purpose of this study is to find out the borax content on rice crackers in traditional markets Tanggamus district by using the qualitative method. It uses the flame test, cucurmin reagen test and ammonia steam test. It also applies quantitative test by using spectophotometry UV-Vis. There are 8 samples which were taken in tradisional markets Tanggamus district. The result of determination of the maximum length waves is $543 \mathrm{~nm}$. This method has been validated before being used for the samples. The resulf of the research shows a curve with linear calibration, with the regression equalition $y=0,539 x+0,009$ and correlation coefficient $(r)=$ 0,9979 . The average recorvery or accuracy value is $104,71 \%$. The precision or the result of standartd deviation and standard deviation relative or coeffecient of variation (CV) is $0,219 \%$. The $L O D$ acquistion value is $0,069 \mu \mathrm{g} / \mathrm{ml}$ and the $L O Q$ is $0,320 \mu \mathrm{g} / \mathrm{ml}$. The validation of the test shows that all methods have been done are valid, so it can be used to test the borax assay on the samples. Based on the analysis on 8 samples of rice crackers, quanlitative obtained sample testing shows 6 detected containing borax, then the result of quantitative obtained the level of borax ranged from 46,75 $\mu \mathrm{g} / \mathrm{g}$ until $107 \mu \mathrm{g} / \mathrm{g}$.
\end{abstract}

Keywords : borax, rice crackers, Spectrofometry UV-Vis

\begin{abstract}
Abstrak
Penggunaan bahan tambahan pangan bertujuan untuk meningkatkan atau mempertahankan nilai gizi dan kualitas daya simpan. Pemerintah melarang penggunaan boraks sebagai bahan tambahan pangan, ditetapkan dalam Permenkes No.033 tahun 2012. Boraks merupakan senyawa kimia berbentuk kristal berwarna putih dengan rumus kimia $\mathrm{Na}_{2} \mathrm{~B}_{4} \mathrm{O}_{7} .10 \mathrm{H}_{2} \mathrm{O}$. Kerupuk nasi adalah kerupuk yang terbuat dari nasi dengan bumbu rempah dan penambah rasa. Untuk mendapatkan kerupuk yang gurih dan dapat mengembang kadang ditambahkan boraks dalam pembuatannya.Tujuan penelitian ini adalah untuk mengetahui kandungan boraks pada kerupuk nasi yang dijual di pasar tradisional
\end{abstract}


Kabupaten Tanggamus dengan menggunakan metode kualitatif yaitu uji nyala, uji pereaksi kurkurmin,uji uap amonia, serta uji kuantitatif menggunakan Spektrofotometri UV-Vis. Ada 8 sampel yang diambil dari pasar tradisional Kabupaten Tanggamus. Hasil penentuan panjang gelombang maksimum $543 \mathrm{~nm}$. Sebelum sampel yang diambil dari 4 pasar tradisional Kabupaten Tanggamus dianalisis,metode ini divalidasi. Hasil dari penelitian menunjukkan kurva kalibrasi linier dengan persamaan regresi $y=0,539 x+0,009$ dan koefisien korelasi $(r)$ $=0,9979$. Nilai rata-rata persen perolehan kembali atau accuracy adalah $104,71 \%$, kesaksamaan atau hasil simpangan baku dan simpangan baku relatif atau koefisien variasi (KV) adalah 0,219\%, nilai LOD adalah $0,069 \mu \mathrm{g} / \mathrm{ml}$ dan LOQ adalah 0,230 $\mu \mathrm{g} / \mathrm{ml}$. Uji validasi tersebut menunjukkan bahwa semua metode yang telah dilakukan valid, sehingga dapat digunakan dalam penetapan kadar boraks pada sampel. Berdasarkan hasil penelitian 8 sampel kerupuk nasi, hasil uji kualitatif: 6 sampel terdeteksi mengandung boraks, kemudian dilakukan uji kuantitatif diperoleh kadar boraks berkisar antara 46,75 $\mu \mathrm{g} / \mathrm{g}$ hingga $107 \mu \mathrm{g} / \mathrm{g}$.

Kata Kunci : boraks, kerupuk nasi, Spektrofotometri UV-Vis

\section{PENDAHULUAN}

Bahan tambahan pada pangan mempunyai peran yang penting dalam proses produksi pangan. Penggunaan bahan tambahan pangan bertujuan untuk meningkatkan atau mempertahankan nilai gizi dan kualitas daya simpan, membuat bahan pangan mudah dihidangkan, serta mempermudah preparasi bahan pangan. Bahan tambahan pangan yang digunakan hanya dapat dibenarkan apabila bertujuan untuk mencapai masing-masing tujuan penggunaan dalam pengolahan, tidak digunakan untuk menyembunyikan penggunaan bahan yang salah atau tidak memenuhi persyaratan, tidak digunakan untuk menyembunyikan cara kerja yang bertentangan dengan cara produksi yang baik untuk pangan, serta tidak digunakan untuk menyembunyikan kerusakan bahan pangan [1].

Boraks merupakan senyawa kimia berbentuk kristal berwarna putih dengan rumus kimia $\mathrm{Na}_{2} \mathrm{~B}_{4} \mathrm{O}_{7} .10 \mathrm{H}_{2} \mathrm{O}$. Boraks digunakan dalam industri kaca, porselin, alat pembersih, bahan pestisida dan bahan pengawet lainnya. Selain itu, di bidang farmasi boraks digunakan sebagai antiseptik, bahan dalam pembuatan salep. Pada beberapa laporan penelitian, boraks telah digunakan sebagai bahan tambahan pangan, seperti kerupuk, bakso, lontong, mie dan tahu. Penambahan boraks bertujuan untuk memberikan tekstur padat, kekenyalan, kerenyahan, memberikan rasa gurih serta bersifat tahan lama terutama bahan makanan yang mengandung pati [2].

Beberapa penelitian telah dilakukan berkaitan dengan penambahan boraks pada bahan makanan. Penelitian yang dilakukan terhadap 10 sampel pempek dan 10 sampel bakso ikan yang beredar di pasar Teluk Betung, terdeteksi 3 dari 10 sampel bakso ikan mengandung boraks [3]. Hasil penelitian pada keripik tempe di pasar tradisional Bandar Lampung, dinyatakan bahwa dari 4 sampel semuanya terdeteksi mengandung boraks [4]. Berdasarkan hasil pengujian Dinas Kesehatan Kabupaten Pringsewu telah ditemukan makanan yang mengandung boraks pada kerupuk nasi dan pada bakso [5]. Seseorang mengonsumsi makanan yang mengandung boraks berlebih dengan kadar mencapai $2 \mathrm{~g} / \mathrm{kg}$ dapat menyebabkan keracunan, dengan gejala antara lain: iritasi kulit dan saluran pernapasan, gangguan pencernaan seperti mual, muntah, nyeri perut dan diare serta gejala keracunan berat yangdapat menyebabkan ruam kulit, penurunan kesadaran, depresi napas dan gagal ginjal. Oleh karena efek toksisitasnya, boraks sangat berbahaya bagi kesehatan manusia, maka pemerintah Indonesia melarang penggunaan boraks sebagai bahan tambahan pangan [2]. Hal tersebut tertuang dalam Peraturan Menteri 
Kesehatan Republik Indonesia No. 033 tahun 2012 [6].

Selain efek toksisitas, jika dikonsumsi dalam jangka panjang boraks juga akan mengakibatkan: depresi sirkular, takikardi, sianosis, kejang hingga koma. Dari percobaan dengan tikus menunjukkan bahwa boraks bersifat karsinogenik. Selain itu boraks juga menyebabkan gangguan pada janin, gangguan reproduksi, menimbulkan iritasi pada lambung, menyebabkan gangguan pada ginjal, hati dan testis [7].

Kerupuk nasi adalah kerupuk yang dibuat dari nasi yang diberi bumbu rempah dan penambah rasa. Untuk mendapatkan kerupuk yang gurih dan dapat mengembang kadang ditambahkan boraks atau ditambahkan tepung tapioka agar adonan mentahnya menjadi kenyal dan padat. Penambahan boraks pada kerupuk bisa memperbaiki tekstur kerupuk, sehingga menghasilkan kerupuk yang bagus dan menarik. Kerupuk yang mengandung boraks kalau digoreng akan mengembang, empuk, teksturnya bagus, dan renyah [8].

Tanggamus adalah salah satu Kabupaten di Provinsi Lampung, yang merupakan daerah pegunungan dan juga daerah pantai. Mata pencaharian masyarakat di Kabupaten Tanggamus pada umumnya adalah sebagai nelayan, petani, dan pedagang. Tanggamus termasuk daerah yang sangat pesat perkembangannya dalam bidang perekonomian. Perdagangan merupakan subsektor unggulan dalam perekonomian di Kabupaten Tanggamus, termasuk perdagangan makanan.

Kerupuk sering dikenal sebagai pendamping makanan. Kerupuk bukan makanan utama dan tidak mengandung vitamin. Kendati demikian, kerupuk tetap menjadi pendamping makanan yang digemari banyak orang [9].

Deteksi boraks telah banyak dilakukan, baik secara kualitatif maupun kuantitatif, seperti uji nyala, uji kertas kurkurmin, tetrasi volumetrik, maupun spektrofotometri. Dalam penelitian ini, peneliti bermaksud menggunakan analisis kuantitatif dengan menggunakan spektrofotometri UV-Vis karena caranya sederhana, dapat menganalisis larutan dalam konsentrasi yang sangat kecil, memiliki kepekaan yang tinggi, ketelitian tinggi, tidak rumit dan cepat, dengan demikian, peneliti mengharapkan alat yang dipakai sungguh menghasilkan informasi yang akurat [10].

\section{METODE PENELITIAN}

\section{Alat dan Bahan}

Alat :

Corong gelas, cawan porselin, pipet tetes, pipet volumetri, labu ukur, gelas ukur, tabung reaksi, blender, kertas saring, timbangan analitik digital, sentrifuge, batang pengaduk, Oven, waterbath, dan spektrofometri UV-Vis Ganesya

\section{Bahan :}

Kerupuk nasi, Natrium tetraborat anhidrat $\left(\mathrm{Na}_{2} \mathrm{~B}_{4} \mathrm{O}_{7}\right) \mathrm{pa}$, Aquades $\left(\mathrm{H}_{2} \mathrm{O}\right) \mathrm{pa}$, Etanol $95 \%\left(\mathrm{C}_{2} \mathrm{H}_{5} \mathrm{OH}\right)$ pa, Asam sulfat pekat $\left(\mathrm{H}_{2} \mathrm{SO}_{4}\right)$, Kurkurmin $\left(\mathrm{C}_{21} \mathrm{H}_{20} \mathrm{O}_{6}\right)$ pa, Asam asetat glasial $\left(\mathrm{CH}_{3} \mathrm{COO}^{-}\right)$, Natrium Hidroksida $(\mathrm{NaOH})$, Amonia $\left(\mathrm{NH}_{3}\right)$, Asam Klorida $(\mathrm{HCl}) 1 \mathrm{~N}$.

\section{Analisis Kualitatif Pada Sampel Kerupuk Nasi}

Sampel kerupuk nasi diperoleh dari 4 pasar di Kabupaten Tanggamus. Setiap sampel ditimbang sebanyak $25 \mathrm{~g}$, kemudian dipotong menjadi ukuran kecil, lalu dihaluskan dengan blender.Sampel yang telah dihaluskan dimasukkan ke dalam plastik dan diberi label. Selanjutnya dilakukan analisis kualitatif dengan cara tiap sampel ditimbang $5 \mathrm{~g}$ masukkan ke dalam beker glas lalu ditambahkan $1 \mathrm{ml}$ $\mathrm{HCl} 1 \mathrm{~N}$, kemudian ditambahkan $20 \mathrm{ml}$ aquadest, dibiarkan selama 1 jam. Kemudian larutan tersebut dimasukkan ke dalam tabung sentrifugasi. Larutan disentrifugasi selama 2 menit dengan kecepatan $3000 \mathrm{rpm}$ lalu diambil supernatan yang diperoleh. Analisis 
secara kualitatif dilakukan dengan uji nyala dengan cara diambil $5 \mathrm{ml}$ dari tiap supernatan sampel, dimasukkan ke dalam cawan poselin diuapkan diatas penangas air sampai kering lalu didinginkan, ditambah 5 tetes $\mathrm{H}_{2} \mathrm{SO}_{4}$ pekat kemudian tambah $1 \mathrm{ml}$ etanol kemudian dibakar, diamati apakah terjadi nyala warna hijau. Uji dengan pereaksi kurkumin dilakukan dengan cara meneteskan supernatan sampel pada kertas kurkurmin apakah terdapat perubahan dari warna jingga menjadi warna merah kecoklatan. Uji dengan uap amonia dilakukan dengan meneteskan supernatan sampel pada kertas kurkurmin kemudian dengan batang pengaduk kertas kurkurmin tersebut dimasukkan kedalam tabung reaksi yang telah diisi dengan amonia, diamati apakah ada perubahan warna pada kertas kurkurmin menjadi abu-abu kehitaman [11].

\section{Analisis Kuantitatif}

\section{Pembuatan Larutan Baku Standar Natrium tetraborat}

Larutan baku standar natrium tetraborat $500 \mu \mathrm{g} / \mathrm{ml}$

Ditimbang natrium tetraborat $0,05 \mathrm{~g}$ dimasukkan ke dalam labu ukur $100 \mathrm{ml}$, lalu ditambahkan aquadest sampai garis batas [7].

Larutan baku standar natrium tetraborat $25 \mu \mathrm{g} / \mathrm{ml}$

Dari larutan standar natrium tetraborat 500 $\mu \mathrm{g} / \mathrm{ml}$ dipipet $2,5 \mathrm{ml}$ dimasukkan dalam labu $50 \mathrm{ml}$ lalu ditambahkan aquadest sampai tanda batas [7].

\section{Penentuan Panjang Gelombang Maksimum Larutan Baku Dan Penentuan Kurva Baku Larutan Natrium Tetraborat}

Dari larutan baku standar Natrium tetraborat konsentrasi $25 \mu \mathrm{g} / \mathrm{ml}$ diambil dengan pipet sebanyak $0,2 \mathrm{ml}, 0,4 \mathrm{ml}, 0,6$ $\mathrm{ml}, 0,8 \mathrm{ml}$ dan $1 \mathrm{ml}$. Kemudian tiap konsentrasi larutan tersebut dimasukkan ke dalam cawan porselin, ditambah $1 \mathrm{ml}$ larutan $\mathrm{NaOH} 10 \%$ lalu dipanaskan pada penangas air sampai kering. Pemanasan dilanjutkan dengan oven pada suhu $100^{\circ} \mathrm{C}$ selama 5 menit, didinginkan. Tambah $3 \mathrm{ml}$ larutan kukurmin 0,125\% dipanaskan sampai 5 menit, dinginkan, kemudian ditambah $3 \mathrm{ml}$ larutan sulfat-asetat (1:1) sambil diaduk dengan batang pengaduk. Diamkan sampai 15 menit, tambahkan etanol kemudian disaring dengan kertas saring, masukkan dalam labu ukur $25 \mathrm{ml}$ dan diencerkan dengan etanol sampai tanda batas. Konsentrasi larutan standar setelah pengenceran adalah $0,2 \mu \mathrm{g} / \mathrm{ml}$, $0,4 \mu \mathrm{g} / \mathrm{ml}, \quad 0,6 \mu \mathrm{g} / \mathrm{ml}, \quad 0,8 \mu \mathrm{g} / \mathrm{ml}$, dan $1 \mu \mathrm{g} / \mathrm{ml}[12]$.

\section{Penentuan panjang gelombang}

Diambil dengan pipet sebanyak $1 \mathrm{ml}$ dari konsentrasi larutan $0,6 \mu \mathrm{g} / \mathrm{ml}$ dimasukkan pada kuvet lalu dibaca absorbansinya pada panjang gelombang $500-800 \mathrm{~nm}$ dengan Spektrofotometri UV-Vis. Diamati dan dicatat panjang gelombang maksimumnya [13].

\section{Penentuan kurva baku larutan natrium tetraborat}

Tiap larutan diambil dengan pipet sebanyak $1 \mathrm{ml}$ dari konsentrasi $0,2 \mu \mathrm{g} / \mathrm{ml}$; $0,4 \mu \mathrm{g} / \mathrm{ml} ; 0,6 \mu \mathrm{g} / \mathrm{ml} ; 0,8 \mu \mathrm{g} / \mathrm{ml}$ dan $1 \mu \mathrm{g} / \mathrm{ml}$ kemudian dimasukkan ke dalam kuvet lalu dibaca absorbansinya dengan Spektrofotometri UV-Vis pada panjang gelombang maksimum [8].

\section{Pembuatan Simulasi Kerupuk Nasi Dengan Penambahan Boraks dan Validasi Metode}

Kerupuk tanpa boraks yang telah dibuat ditimbang sebanyak 5 kali penimbangan. Tiap penimbangan sebanyak $5 \mathrm{~g}$ dimasukkan ke dalam beker glass. Pada setiap penimbangan ditambahkan $1 \mathrm{mg}, 2$ $\mathrm{mg}, 3 \mathrm{mg}, 4 \mathrm{mg}$ dan $5 \mathrm{mg}$ serbuk boraks. Lalu ditambahkan $1 \mathrm{ml} \mathrm{HCl} 1 \mathrm{~N}$, dan 100 $\mathrm{ml}$ aquadest diamkan selama 1 jam. Campuran dimasukkan ke dalam tabung sentrifuge kemudian alat dioperasikan selama 2 menit dengan kecepatan 3000 rpm, kemudian diambil supernatannya sehingga diperoleh konsentrasi 0,01 $\mathrm{mg} / \mathrm{ml} ; \quad 0,02 \mathrm{mg} / \mathrm{ml} ; 0,03 \mathrm{mg} / \mathrm{ml} ; 0,04$ $\mathrm{mg} / \mathrm{ml}$, dan $0,05 \mathrm{mg} / \mathrm{ml}$ [8]. 


\section{Metode validasi}

Diambil dengan pipet sebanyak $1 \mathrm{ml}$ larutan natrium tetraborat dari preparasi simulasi kerupuk $10 \mu \mathrm{g} / \mathrm{ml}, 20 \mu \mathrm{g} / \mathrm{ml}$, $30 \mu \mathrm{g} / \mathrm{ml}$, $\quad 40 \mu \mathrm{g} / \mathrm{ml}$ dan $50 \mu \mathrm{g} / \mathrm{ml}$, dimasukkan kedalam cawan porselin, lalu ditambahkan $1 \mathrm{ml} \mathrm{NaOH} 10 \%$, dipanaskan diatas penangas air sampai kering. Pemanasan dilanjutkan dengan oven pada suhu $100^{\circ} \mathrm{C}$ selama 5 menit, didinginkan. Tambahkan $3 \mathrm{ml}$ larutan kukurmin $0,125 \%$ dipanaskan sampai 5 menit, dinginkan, lalu ditambahkan $3 \mathrm{ml}$ larutan sulfat-asetat (1:1) sambil diaduk dengan batang pengaduk. Didiamkan sampai 15 menit, lalu tambahkan etanol, larutan kemudian disaring dengan kertas saring, masukkan dalam labu ukur 100 ml, tambahkan etanol sampai tanda batas. Lalu dibaca absorbansinya dengan spektrofotometri UV-Vis pada panjang gelombang maksimum dilakukan pengulangan sebanyak tiga kali.Dari hasil absorbansi kemudian dilakukan perhitungan nilai akurasi, presisi, nilai linieritas, LOD dan LOQ [8].

\section{Penetapan Kadar Boraks Pada Kerupuk Nasi}

Sebanyak $5 \mathrm{~g}$ dari tiap sampel kerupuk nasi yang telah dihaluskan dimasukkan kedalam beker glas, ditambah $1 \mathrm{ml} \mathrm{HCl}$ $1 \mathrm{~N}$, ditambah $20 \mathrm{ml}$ aquadest diamkan sampai 1 jam. Lalu larutan disentrifuge selama 2 menit dengan kecepatan 3000 rpm, kemudian diambil supernatannya. Supernatan sampel diambil dengan pipet sebanyak $1 \mathrm{ml}$ ditambah dengan $1 \mathrm{ml}$ larutan $\mathrm{NaOH} 10 \%$, panaskan diatas penangas air hingga kering. Pemanasan dilanjutkan dengan oven pada suhu $100^{\circ} \mathrm{C}$ selama 5 menit, didinginkan tambahkan 3 $\mathrm{ml}$ larutan kukurmin $0,125 \%$ panaskan selama 5 menit, didinginkan, tambahkan 3 $\mathrm{ml}$ larutan sulfat-asetat (1:1) sambil diaduk dengan batang pengaduk, diamkan selama 15 menit, kemudian disaring dengan kertas saring, masukkan ke dalam labu ukur $50 \mathrm{ml}$, ditambah etanol sampai tanda batas. Kemudian dilakukan pengukuran absorbansinya dengan
Spektrofotometri UV-Vis pada panjang gelombang maksimum [8].

\section{HASIL DAN PEMBAHASAN}

\section{Pengambilan Bahan Uji}

Dari 5 pasar yang dipilih untuk pengambilan sampel, hanya 4 pasar yang menjual kerupuk nasi, (Pasar Gisting, Pasar Talang Padang, Pasar Kota Agung, Pasar Gunung Batu), maka dari pasar tradisional yang menjual kerupuk nasi tersebut setiap pasar diambil 2 sampel yang berasal dari penyalur yang berbeda sehingga diperoleh 8 sampel. Dalam proses penyiapan larutan uji menggunakan prinsip prosedur berdasarkan kelarutan boraks, boraks mudah larut dalam air dan kelarutan dalam air bertambah dengan penambahan asam klorida. Proses sentrifugasi dilakukan untuk memisahkan larutan kerupuk nasi dengan endapan kerupuk nasi yang tidak larut. Setelah disentrifugasi terbentuk supernatan dan endapan, kemudian supernatan yang terbentuk dipisahkan. Supernatan yang ditampung adalah sampel yang akan dianalisis kualitatif dan kuantitatifnya.

Mekanisme reaksi :

$\mathrm{Na}_{2} \mathrm{~B}_{4} \mathrm{O}_{7}+2 \mathrm{HCl}+5 \mathrm{H}_{2} \mathrm{O} \rightarrow 4 \mathrm{H}_{3} \mathrm{BO}_{3}+2 \mathrm{NaCl}$

\section{Hasil Analisis Kualitatif Kerupuk Nasi}

Hasil uji boraks pada kerupuk nasi secara kualitatif telah dilakukan yaitu dengan uji nyala, uji dengan pereaksi kurkurmin dan uji uap amonia dapat dilihat pada tabel 1.

\section{Uji Nyala}

Hasil uji nyala menunjukkan bahwa semua sampel kerupuk nasi tidak teridentifikasi adanya boraks. Sampel yang mengandung boraks menunjukkan nyala berwarna hijau yang disebabkan oleh terbentuknya etil borat $\left(\mathrm{B}\left(\mathrm{OC}_{2} \mathrm{H}_{5}\right)_{3}\right.$ [11]. Reaksi yang terjadi sebagai berikut :

$$
\begin{aligned}
& \mathrm{Na}_{2} \mathrm{~B}_{4} \mathrm{O}_{7}+\mathrm{H}_{2} \mathrm{SO}_{4}+5 \mathrm{H}_{2} \mathrm{O} \rightarrow 4 \mathrm{H}_{3} \mathrm{BO}_{3}+2 \mathrm{Na}^{+} \\
& +\mathrm{SO}_{4}{ }^{2-} \\
& \mathrm{H}_{3} \mathrm{BO}_{3}+3 \mathrm{C}_{2} \mathrm{H}_{5} \mathrm{OH} \rightarrow \mathrm{B}\left(\mathrm{OC}_{2} \mathrm{H}_{5}\right)_{3}+3 \mathrm{H}_{2} \mathrm{O}
\end{aligned}
$$


Tujuan penambahan asam sulfat pekat yaitu untuk memberikan suasana asam pada sampel untuk membantu melarutkan garam borat menjadi asam borat.

Tabel 1 Hasil pengamatan boraks pada uji kualitatif

\begin{tabular}{c|c|c|c|c}
\hline No & Sampel & $\begin{array}{c}\text { Uji } \\
\text { Nyala } \\
\text { Api }\end{array}$ & $\begin{array}{c}\text { Uji Pereaksi } \\
\text { Kurkurmin }\end{array}$ & $\begin{array}{c}\text { Uji Uap } \\
\text { Amonia }\end{array}$ \\
\hline 1 & $\mathrm{~A}_{1}$ & - & + & - \\
\hline 2 & $\mathrm{~A}_{2}$ & - & - & - \\
\hline 3 & $\mathrm{~B}_{1}$ & - & + & - \\
\hline 4 & $\mathrm{~B}_{2}$ & - & + & - \\
\hline 5 & $\mathrm{C}_{1}$ & - & + & - \\
\hline 6 & $\mathrm{C}_{2}$ & - & + & - \\
\hline 7 & $\mathrm{D}_{1}$ & - & - & - \\
\hline 8 & $\mathrm{D}_{2}$ & - & + & - \\
\hline
\end{tabular}

Keterangan :

$(-)=$ Tidak terdeteksi boraks

$(+)=$ Positif mengandung Boraks

\section{Uji Pereaksi Kurkurmin}

Hasil uji dengan pereaksi kukurmin dari 8 sampel terdapat 6 sampel teridentifikasi adanya boraks, yang diamati terjadinya perubahan warna pada kertas kukumin dari warna kuning menjadi merah kecoklatan. Apabila sampel mengandung boraks maka asam boraks dengan kukurmin akan membentuk komplek kelat rosasianin yaitu warna merah karmesin [14]. Reaksi yang terjadi adalah sebagai berikut:

$\mathrm{Na}_{2} \mathrm{~B}_{4} \mathrm{O}_{7}+2 \mathrm{HCl}+5 \mathrm{H}_{2} \mathrm{O} \rightarrow 4 \mathrm{H}_{3} \mathrm{BO}_{3}+2 \mathrm{Na}^{+}+$ $2 \mathrm{Cl}^{-}[11]$.

\section{Uji Uap Amonia}

Hasil uji uap amonia, semua sampel tidak terjadi perubahan warna dari coklat kemerahan menjadi abu-abu kehitaman dari hasil pengamatan perubahan warna

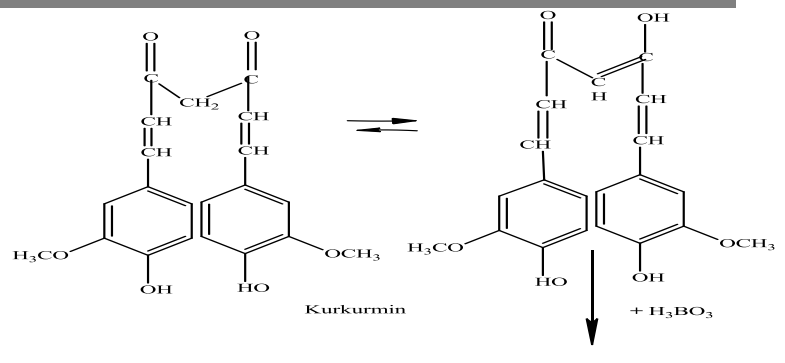

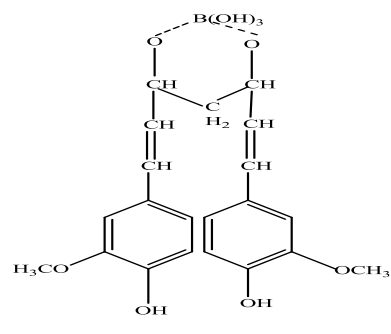

Gambar 1. Reaksi asam borat dengan kurkurmin

\section{Hasil Analisis Kuantitatif}

\section{Penentuan Panjang Gelombang}

Hasil pengukuran panjang gelombang serapan maksimum dari larutan baku standar natrium tetraborat dari penelitian ini adalah $543 \mathrm{~nm}$.

\section{Penentuan Kurva Baku Larutan Natrium tetraborat}

Pada pembuatan kurva kalibrasi larutan natrium tetraborat dilakukan dengan membuat berbagai konsentrasi pengukuran yaitu $0,2 \mu \mathrm{g} / \mathrm{ml} ; 0,4 \mu \mathrm{g} / \mathrm{ml} ; 0,6$ $\mu \mathrm{g} / \mathrm{ml} ; 0,8 \mu \mathrm{g} / \mathrm{ml}$ dan $1,0 \mu \mathrm{g} / \mathrm{ml}$ kemudian diukur serapannya pada panjang gelombang $543 \mathrm{~nm}$. Hasil diperoleh dapat dilihat pada tabel 2

Tabel 2 Hasil pengukuran absorbansi larutan standar boraks

\begin{tabular}{l|c|c}
\hline No & $\begin{array}{l}\text { Konsentrasi } \\
(\boldsymbol{\mu} \mathbf{g} / \mathbf{m l})\end{array}$ & Absorbansi \\
\hline 1 & 0,0 & 0,000 \\
\hline 2 & 0,2 & 0,130 \\
\hline 3 & 0,4 & 0,229 \\
\hline 4 & 0,6 & 0,335 \\
\hline 5 & 0,8 & 0,420 \\
\hline 6 & 1,0 & 0,560 \\
\hline
\end{tabular}


Hasil pengukuran absorbansi selanjutnya digunakan untuk membuat kurva kalibrasi, seperti terlihat pada gambar 2 dibawah ini

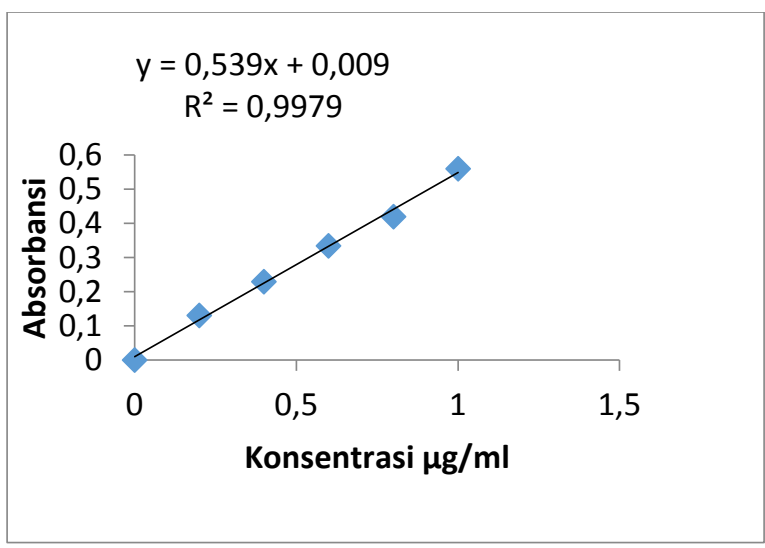

Gambar 2. Kurva Baku Standar Boraks

Pembuatan larutan kurva kalibrasi natrium tetraborat menghasilkan persamaan regresi linier $y=0,539 x+0,009$ dengan koefisien korelasi ( $r$ ) sebesar 0,9979. Harga koefisien korelasi yang mendekati 1 menyatakan hubungan yang linier antara konsentrasi dan serapan yang dihasilkan, dengan kata lain peningkatan nilai absorbansi analit berbanding lurus dengan peningkatan konsentrasi. Kriteria penerimaan dari koefisien korelasi ( $r$ ) adalah sebesar $\geq 0,9995$ yang berarti bahwa hasil absorbansi dari kurva kalibrasi masih linier, yaitu apabila ada peningkatan konsentrasi, absorbansi juga meningkat [15]. Dari penelitian ini dengan nilai koefisien korelasi sebesar 0,9979 memenuhi kriteria linier

\section{Validasi Metode}

Pada penelitian ini diperoleh :

Ketepatan (Accuracy)

Uji ketepatan merupakan derajat kedekatan hasil yang diperoleh dengan kadar analit yang sebenarnya. Pada penelitian ini uji ketepatan dengan mengukur absorbansi dari tiap konsentrasi larutan simulasi kerupuk berboraks yaitu $0,3 \mu \mathrm{g} / \mathrm{ml} ; 0,4 \mu \mathrm{g} / \mathrm{ml}$ dan $0,5 \mu \mathrm{g} / \mathrm{ml}$ [8]. Ketepatan metode dapat dilihat dari hasil persen perolehan kembali boraks pada kerupuk nasi. Rata-rata perolehan kembali yang diperoleh dalam penelitian ini adalah $104,77 \%$.

\section{Kesaksamaan (Presicion)}

Kesaksamaan adalah ukuran yang menunjukkan derajat kesesuaian antara hasil uindividual dari rata-rata jika prosedur diterapkan secara berulang pada sampel yang diambil dari campuran homogen. Kriteria saksama diberikan jika metode memberikan simpangan baku relatif atau koefisien vareasi $\leq 2 \%$ [16]. Nilai koefisian variasi yang diperoleh dari penelitian ini adalah $0,219 \%$ dari nilai perolehan tersebut bahwa dari penelitian ini memenuhi kriteria saksama [15].

\section{Penentuan nilai LOD dan LOQ}

Pada penelitian ini diperoleh nilai LOD (batas deteksi) sebesar 0,069 $\mu \mathrm{g} / \mathrm{ml}$ yang berarti bahwa pada konsentrasi tersebut masih dapat dilakukan pengukuran sampel yang memberi hasil ketelitian alat berdasarkan tingkat akurasi individual hasil analisis [15]. Sedangkan nilai kuantitasi (LOQ) sebesar $0,230 \mu \mathrm{g} / \mathrm{ml}$ yang berarti pada konsentrasi tersebut bila dilakukan pengukuran masih dapat memberikan kecermatan analisis [15].

\section{Penentuan Kadar Boraks Dalam Sampel}

Hasil pengukuran kadar boraks pada kerupuk nasi yang dijual di Pasar Tradisional Kabupaten Tanggamus terdiri dari 6 sampel yang terdeteksi mengandung boraks dengan kadar terendah 46,75 $\mu \mathrm{g} / \mathrm{g}$ dan kadar tertinggi sebesar $107 \mu \mathrm{g} / \mathrm{g}$. Hasil penetapan kadar boraks pada sampel kerupuk nasi setelah diukur dengan alat spektrofotometri UVVis tertera pada tabel 3 dan pada gambar grafik 3 : 
Tabel 3 Hasil absorbansi sampel dan kadar yang diperoleh

\begin{tabular}{l|l|c|c}
\hline NO & \multicolumn{1}{|c|}{ Sampel } & $\begin{array}{c}\text { Absorban } \\
\text { si Sampel }\end{array}$ & $\begin{array}{c}\text { Kadar Boraks } \\
\text { dalam Sampel } \\
(\boldsymbol{\mu g} / \mathbf{g})\end{array}$ \\
\hline 1 & $\begin{array}{l}\text { Pasar Gisting } \\
(\text { Sampel A1) }\end{array}$ & 0,240 & 107 \\
2 & $\begin{array}{l}\text { Pasar Gunung } \\
\text { Batu (Sampel } \\
\text { B1) }\end{array}$ & 0,130 & 56 \\
3 & $\begin{array}{l}\text { Pasar Gunung } \\
\text { Batu (Sampel } \\
\text { B2) }\end{array}$ & 0,206 & 91,25 \\
\hline 4 & $\begin{array}{l}\text { Pasar } \\
\text { Talangpadang } \\
(\text { Sampel C1) }\end{array}$ & 0,110 & 46,75 \\
\hline 5 & $\begin{array}{l}\text { Pasar } \\
\text { Talangpadang } \\
(\text { Sampel C2) }\end{array}$ & 0,160 & 70 \\
\hline & $\begin{array}{l}\text { Pasar Kota } \\
\text { Agung (Sampel } \\
\text { D2) }\end{array}$ & 0,170 & 74,5 \\
\hline
\end{tabular}

Kadar Boraks dalam Sampel

- Absorbansi Sampel

- Kadar Boraks dalam Sampel ( $\mu \mathrm{g} / \mathrm{g}$ )

107

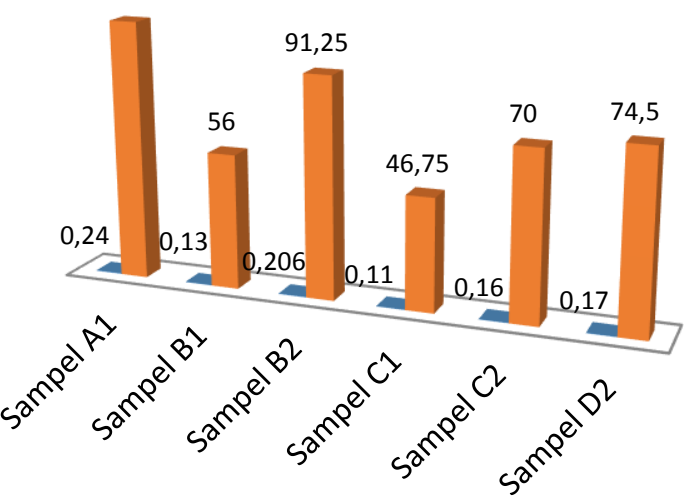

Gambar 3. Kadar boraks pada kerupuk nasi yang dijual di pasar tradisional Kabupaten Tanggamus

\section{KESIMPULAN DAN SARAN}

\section{KESIMPULAN}

Berdasarkan hasil penelitian yang telah dilakukan, dapat diambil kesimpulan bahwa:

1. Hasil uji kualitatif kerupuk nasi yang dijual di empat pasar tradisional Kabupaten Tanggamus terhadap 8sampel, 6 sampel atau $75 \%$ positif terdeteksi mengandung boraks.
2. Hasil Analisis kandungan boraks pada kerupuk nasi yang dijual di pasar tradisional Kabupaten Tanggamus 6 sampel terdeteksi mengandung boraks dengan kadar boraks berkisar antara 46,75 $\mu \mathrm{g} / \mathrm{g}$ hingga $107 \mu \mathrm{g} / \mathrm{g}$.

\section{DAFTAR PUSTAKA}

[1] Cahyadi W. 2009. Analisis \& Aspek Kesehatan Bahan Tambahan Pangan. II. Bandung:Penerbit Bumi Aksara. $386 \mathrm{p}$.

[2] Fuad NR. 2014.Identifikasi Kandungan Boraks pada Tahu Pasar Tradisional di Daerah Ciputat.(Skripsi) Universitas Islam Negeri Jakarta.

[3] Ulfa AM.2015. Identifikasi Boraks pada Pempek dan Bakso Ikan secara Reaksi Nyala dan Reaksi Warna. J Kesehat Holistik. 9(3):1517.

[4] Khasanah U. 2017. Analisis Kandungan Boraks Pada Keripik Tempe Yang dijual Di Pasar Tradisional Kota Bandar Lampung (Skripsi). Fakultas Matematika dan IImu Pengetahuan Alam Universitas Tulang Bawang Lampung.

[5] Lampung Tribun.2014.Beredar Kerupuk Mengandung Boraks di Pringsewu.2.

[6] Departemen Kesehatan Republik Indonesia. 2012. Undang-Undang Republik IndonesiaNomor 18 Tahun 2012 Tentang Pangan. 18(9):168999.

[7] Widayat D. 2011.Uji Kandungan Boraks pada Bakso. Universitas Jember

[8] Fitry A, Rusnaeni ESS.2017. Penetapan Kadar Boraks Pada Kerupuk Olahan Di Distrik Heram Kota Jayapura Menggunakan Spektrofotometer UV-VIS. Pharmacon J Ilm Farm. 6(3):285-90.

[9] Muharrami LK. 2015. Analisis 
kualitatif kandungan boraks pada krupuk puli di kecamatan kamal. $J$ pena Sains. 2(2).

[10] Mulya M \& Suharman.1995.Analisis Instrumental. Surabaya: Airlangga University Press. 6-11, 26-33 p.

[11] G.Svehva.1979. VOGEL. Jakarta. Penerbit Pt. Kalman Media Pustaka. 365-369 p.

[12] Qafah A. 2013.Analisis Kadar Boraks pada Kurma Yang Beredar Di Pasar Tanah Abang Dengan Menggunakan Spektrofotometer UVVis(Skripsi). UIN Syarif Hidayatullah. Jakarta.

[13] Musiam S. 2017. Validasi Metode Spektrofotometri UV pada Analisis Penetapan Kadar Asam Mefenamat dalam Sediaan Tablet Generik. J IIm Ibnu Sina. 2(1):31-43.

[14] Hartati FK.2017. Analisis Boraks Secara Cepat, Mudah Dan Murah Pada Kerupuk. J Teknol Proses danInov Ind.2(1):33-7.

[15] Riyanto. 2014.Validasi \& Verifikasi Metode Uji. Yokyakarta: Cv. Budi Utama. 9-78 p.

[16] Ibnu Glolib Gandjar \& Rohman A.2010. Kimia Farmasi Analisis. Yoyakarta: Pustaka Pelajar. 490 p. 